\title{
Peran Komite Audit sebagai Pemoderasi Atas Determinan Persistensi Laba Perusahaan Pertambangan
}

Wawan Awaludin ${ }^{1}$, Darmansyah ${ }^{2}$

${ }^{1.2}$ Universitas Pancasila, Jl. Srengseng Sawah, Jagakarsa, Jakarta Selatan, 12640

\author{
INFO ARTIKEL \\ JEL Classsification: \\ M41 \\ 016
}

Keywords:

Audit Committee, Operating Cash Flow,

Debt Level, Earning

Persistence

\section{ABSTRACT}

This study aims to examine operational cash flows, debt levels, and firm size against earnings persistence, in moderation with an audit committee. Samples are 25 mining companies listed on the Indonesia Stock Exchange for 5 years. The results of the study prove that operational cash flows, debt levels have a significant effect on earnings persistence, firm size has a negative effect on earnings persistence. The committee of committee can moderate the effect of cash flow on earnings persistence. The audit committee cannot moderate the influence of the level of debt and company size on earnings persistence. The results of the study are expected to be a consideration for investors in investing in the capital market. Decision-making should be based on financial ratios, among others, operational cash flow, debt level and company size, and for issuers expected in business expansion must consider financial ratios, including operational cash flow, debt level and company size.

\begin{abstract}
ABSTRAK
Penelitian ini bertujuan untuk menguji arus kas operasional, tingkat hutang, dan ukuran perusahaan terhadap persistensi laba, di moderasi dengan audit committee. Sampel adalah 25 perusahaan pertambangan yang terdaftar di Bursa Efek Indonesia selama 5 tahun. Hasil penelitian membuktikan bahwa arus kas operasional, tingkat hutang berpengaruh signifikan terhadap persistensi laba, ukuran perusahaan berpengaruh negatif terhadap persistensi laba. Komite uadit dapat memoderasi pengaruh arus kas terhadap persistensi laba. Komite audit tidak dapat memoderasi pengaruh tingkat hutang dan ukuran perusahaan terhadap persistensi laba. Hasil penelitian diharapkan dapat menjadi pertimbangan bagi investor dalam melakukan investasi di pasar modal. Pengambilan keputusan seharusnya didasarkan pada rasio keuangan, antara lain, arus kas operasional, tingkat hutang dan ukuran perusahaan, dan bagi emiten diharapkan dalam ekspansi usaha wajib mempertimbangkan rasio keuangan antara lain arus kas operasional, tingkat hutang dan ukuran perusahaan.
\end{abstract}

\section{Pendahuluan}

Persistensi laba diartikan sebagai kemampuan laba suatu perusahaan untuk bertahan di masa depan (Penman, 2002). Laba perusahaan yang mampu bertahan di masa depan inilah yang mencerminkan laba yang berkualitas. Oleh sebab itu, persistensi laba sering dianggap sebagai alat ukur untuk menilai kualitas laba yang berkesinambungan. Laba yang persisten merupakan laba yang cenderung tidak berfluktuatif dan mencerminkan keberlanjutan

*Email Korespondensi: ${ }^{1}$ wawaludin@gmail.com 
laba di masa depan dan berkesinambungan untuk periode yang lama. Persistensi laba menjadi bahasan yang sangat penting karena investor memiliki kepentingan informasi terhadap kinerja perusahaan yang tercermin dalam laba di masa depan.

Informasi mengenai laba yang bersumber dari laporan keuangan yang diberikan perusahaan kepada publik terutama investor atau kreditur. Salah satu unsur dalam laporan keuangan yang paling banyak diperhatikan dan dinantikan informasinya adalah laporan laba rugi, yaitu suatu laporan yang memberikan informasi mengenai laba (earnings) yang dicapai oleh perusahaan dalam suatu periode. Laba yang dipublikasikan dapat memberikan respon yang bervariasi, yang menunjukkan adanya reaksi pasar terhadap informasi laba. Reaksi yang diberikan tergantung dari kualitas laba yang dihasilkan oleh perusahaan. Laba yang berkualitas adalah laba yang mencerminkan kelanjutan laba (sustainable earnings) di masa depan, yang ditentukan salah satunya oleh komponen aliran kas dan dapat mencerminkan kinerja keuangan yang sesungguhnya (Penman, 2002; dalam Fanani, Z. 2010). Laba yang berkualitas adalah laba yang persisten karena persistensi laba merupakan komponen dari karakteristik kualitatif relevansi yaitu nilai prediktif. Persistensi laba adalah laba akuntansi yang diharapkan di masa mendatang (expected future earnings) yang tercermin pada laba tahun berjalan (current earnings) (Penman, 2001; dalam Fanani, Z. 2010). Penman (2003; dalam Sunarto 2008) membedakan laba dalam dua kelompok, yaitu sustainable earnings (earnings persistent atau core earnings), dan unusual earnings atau transitory earnings. Persistensi laba merupakan laba yang mempunyai kemampuan sebagai indikator laba periode mendatang (future earnings) yang dihasilkan oleh perusahaan secara berulang-ulang (repetitive) dalam jangka panjang (sustainable). Sedangkan unusual earnings atau transitory earnings merupakan laba yang dihasilkan secara temporer dan tidak dapat dihasilkan secara berulang-ulang (non-repeating).

Laporan keuangan, termasuk laporan laba rugi merupakan media bagi perusahaan untuk memberikan informasi penting kepada publik, khususnya bagi mereka yang menggunakan laporan keuangan untuk tujuan pengambilan keputusan ekonomi (Jumingan, 2006). Laporan laba rugi merupakan bagian dari laporan keuangan yang menyajikan laba (earnings) yang diperoleh perusahaan dalam suatu periode. Bagi para investor, informasi laba penting untuk mengetahui kualitas laba suatu perusahaan sehingga mereka dapat mengurangi resiko informasi. Investor tidak mengharapkan kualitas informasi laba yang rendah (low quality) karena merupakan sinyal alokasi sumber daya yang kurang baik. Menurut Chandarin (2003) dalam Jang dkk (2007), laba akuntansi yang berkualitas adalah laba akuntansi yang mempunyai sedikit gangguan persepsian di dalamnya dan dapat mencerminkan kinerja keuangan perusahaan yang sesungguhnya. Semakin besar gangguan persepsian yang terkandung dalam laba akuntansi, maka semakin rendah kualitas laba akuntansi tersebut. Sehingga tidak dapat digunakan sebagai indikator laba periode mendatang. Karena persistensi laba merupakan expected future earnings maka ada dua unsur yang mewakili persistensi laba tersebut yaitu perubahan laba sebelum pajak (pretax book income) dan laba bersih (net income) (Jackson, 2009; dalam Martani dan Persada, 2009).

Rasio keuangan perusahaan dapat digunakan oleh investor untuk memprediksi kinerja perusahaan di masa akan datang, hal ini karena likuiditas mencermin kegiatan operasional perusahaan dan kegiatan investasi dalam satu periode tertentu. Fluktuasi dari likuiditas perusahaan akan mempengaruhi kesinambungan laba/persistensi laba, karena akan menimbulkan ketidakpastian dalam operasional perusahaan. Selain dari likuiditas hal yang perlu diperhatikan oleh investor adalah tingkat hutang perusahaan (Leverage). Leverage timbul karena dalam 
operasinya perusahaan menggunakan aktiva dan sumber dana yang menimbulkan biaya tetap. Scott (2003), menyatakan bahwa semakin tinggi tingkat leverage perusahaan akan menyebabkan rendahnya koefisien ERC. Perusahaan yang memiliki prosentase utang tinggi maka laba yang diperoleh perusahaan akan lebih banyak dialokasikan untuk kreditur daripada pemegang saham.

Sesuai dengan permasalahan yang akan diteliti, maka tujuan penelitian antara lain :

Menganalisa dan mengidentifikasi bahwa arus kas operasional berpengaruh terhadap persistensi laba, menguji dan menganalisa adanya pengaruh tingkat hutang terhadap persistensi laba, menguji dan menganalisa adanya pengaruh ukuran perusahaan terhadap persistensi laba, menguji dan menganalisa adanya pengaruh arus kas operasi terhadap persistensi laba jika di moderasi oleh audit committe, menguji dan menganalisa adanya pengaruh tingkat hutang perusahaan terhadap persistensi laba jika di moderasi oleh Audit committe, dan Menguji adanya pengaruh ukuran perusahaan terhadap persistensi laba jika di moderasi oleh Audit committe. Berdasarkan tujuan penelitian maka hasil penelitian ini diharapkan dapat memberikan Manfaat Teoritis baik bagi para akademisi, maupun bagi penelitian selanjutnya di bidang akuntansi dan pasar modal, dan juga manfaat praktis bagi emiten, investor dan bagi regulator

\section{Telaah Teori dan Pengembangan Hipotesis}

Di kembangkan di tahun 1976, terutama pada tulisan Jensen and Meckling (1976), yang berjudul: "Theory of the firm: managerial behaviour, agency cost, and ownership structure". Teori keagenan mendeskripsikan hubungan antara pemegang saham (shareholders) sebagai prinsipal dan manajemen sebagai agen. Manajemen merupakan pihak yang di kontrak oleh pemegang saham untuk bekerja demi kepentingan pemegang saham. Karena mereka di pilih, maka pihak manajemen harus mempertanggung jawabkan semua pekerjaan nya kepada pemegang saham. Jika kedua belah pihak tersebut mempunyai tujuan yang sama untuk memaksimumkan nilai perusahaan, maka di yakini agen akan bertindak dengan cara yang sesuai dengan kepentingan prinsipal. Teori keagenan merupakan basis teori yang mendasari praktik bisnis perusahaan yang dipakai selama ini. Teori tersebut berakar dari sinergi teori ekonomi, teori keputusan, sosiologi, dan teori organisasi.

\section{Hubungan antara Persistensi Laba dengan Arus Kas Operasional}

Informasi tentang arus kas suatu perusahaan berguna bagi pemakai laporan keuangan sebagai dasar untuk menilai kemampuan perusahaan dalam menghasilkan kas dan setara kas. Selain itu kemampuan arus kas untuk meningkatkan daya banding pelaporan kinerja operasi ini merupakan salah satu alasan digunakannya arus kas sebagai sumber informasi oleh investor selain infromasi laba. Sesungguhnya, nilai yang terkandung dalam arus kas operasi pada satu periode mencerminkan nilai laba dalam metode kas. Data arus kas merupakan indikator keuangan yang lebih baik di bandingkan dengan akuntansi karena arus kas relatif sulit untuk dimanipulasi. Biasanya dilakukan melalui penggunaan metode akuntansi yang berbeda untuk transaksi yang sama dengan tujuan menampilkan laba yang di inginkan. Sloan (1996) menjelaskan bahwa volatilitas arus kas memiliki pengaruh negatif terhadap persistensi laba. Hal ini mengindikasikan bahwa derajat volatilitas arus kas bisa memprediksi persistensi laba atau dengan kata lain volatilitas yang tinggi akan menyebabkan persistensi laba yang rendah. Untuk mengukur persistensi laba itu sendiri dibutuhkan arus kas operasi yang stabil, yaitu yang mempunyai fluktuasi yang kecil. Jika arus kas tidak stabil maka sangatlah sulit untuk memprediksi arus kas dimasa yang akan datang. Volatilitas yang tinggi menunjukkan persistensi laba yang rendah. Dimana aliran kas yang 
tidak stabil tersebut mengindikasikan adanya ketidakpastian yang tinggi dalam lingkungan operasi yang ditunjukkan oleh volatilitas arus kas operasi yang tinggi. Dengan kata lain, semakin besar fluktuasi arus kas yang terjadi dalam lingkungan operasi perusahaan akan membuat persistensi laba menjadi semakin rendah.

Ha1 - Arus Kas Operasional berpengaruh signifikan terhadap Persistensi Laba.

\section{Hubungan antara Tingkat Hutang dengan Persistensi Laba}

Hutang adalah semua kewajiban perusahaan kepada pihak-pihak lain yang belum terpenuhi. Dimana hutang ini adalah sumber dana atau modal suatu perusahaan. Menurut FASB (Financial Accounting Standard Board) hutang adalah pengorbanan manfaat ekonomi masa mendatang yang mungkin timbul karena kewajiban sekarang suatu entitas menyerahkan aktiva atau memberikan jasa kepada entitas lain dimasa mendatang sebagai akibat transaksi masa lalu. Scott (2003) menyatakan bahwa semakin tinggi tingkat hutang perusahaan maka laba yang diperoleh perusahaan akan lebih banyak dialokasikan untuk kreditur dari pada pemegang saham. Hutang dapat diklasifikasi menjadi dua jenis, yaitu: hutang lancar (hutang jangka pendek) yaitu kewajiban keuangan perusahaan yang pelunasannya akan dilakukan dalam jangka pendek dengan mengunakan aktiva lancar yang dimiliki perusahaan, dan hutang tidak lancar (hutang jangka panjang) kewajiban keuangan perusahaan yang jangka waktu pembayarannya lebih dari satu tahun sejak tanggal neraca.

Kusuma dan Sadjiarto (2014) menyatakan bahwa salah satu informasi pada laporan keuangan yang dapat mempengaruhi persepsi investor adalah tingkat hutang. Investor akan cenderung berhati-hati atau lebih waspada ketika berinvestasi pada perusahaan yang tingkat hutangnya tinggi. Namun investor akan memiliki pandangan yang lebih baik terhadap perusahaan yang tingkat hutangnya tinggi bila laba perusahaan tersebut persisten atau sesuai dengan keadaan yang sebenarnya dan berkelanjutan.

Penelitian Fanani (2010), memberikan bukti bahwa tingkat hutang berpengaruh positif dan signifikan terhadap persistensi laba. Hal ini berhubungan dengan tingkat solvabilitas keuangan yang di miliki oleh perusahaan. Besarnya tingkat hutang perusahaan akan menyebabkan perusahaan meningkatkan kinerja perusahaan, namun terdapat biaya bunga yang tinggi yang harus di bayar oleh perusahaan dalam jangka waktu tertentu.

Untuk membiayai perusahaan sebaiknya perusahaan mencari sumber lain selain hutang, antara lain pendanaan/ investasi pihak lain, yang biayanya lebih murah dibandingkan dengan hutang.

Berdasarkan penjelasan tersebut maka :

Ha2 - Tingkat Hutang berpengaruh signifikan terhadap Persistensi Laba.

\section{Hubungan antara Ukuran Perusahaan dengan Persistensi Laba}

Ukuran perusahaan pada dasarnya adalah pengelompokkan perusahaan berdasarkan beberapa kelompok. Terdapat beberapa pengertian dari penelitian-penelitian terdahulu, anatara lain : Suwito dan Herawaty (2005) berpendapat bahwa ukuran perusahaan mencerminkan berapa besar kecilnya perusahaan yang di dasarkan pada total asset perusahaan. Menurut Sidharta (2000) ukuran perusahaan adalah skala perusahaan yang dilihat dari total aktiva perusahaan pada akhir tahun. Total penjualan juga dapat digunakan sebagai dasar mengukur besarnya perusahaan.

Penelitian ukuran perusahaan dapat juga menggunakan tolak ukur asset. Karena total asset perusahaan bernilai besar maka hal ini dapat disederhanakan dengan perhitungan sebagai berikut : Size $=$ Total Asset (Ghozali, 2006). Sedangkan menurut Oktavianti, S. (2015) ukuran perusahaan yang biasa di pakai untuk menentukan tingkat perusahaan adalah : tenaga kerja, tingkat penjualan, total hutang dan total 
asset. Investor biasanya akan lebih memiliki kepercayaan terhadap perusahaan besar, karena perusahaan besar dianggap mampu untuk terus meningkatkan kinerja perusahaannya dengan berupaya meningkatkan kualitas labanya. Dengan demikian, semakin besar ukuran perusahaan akan membuat investor semakin merespon laba yang di umumkan.

\section{Hubungan antara Peristensi Laba dengan Ukuran Perusahaan}

Seperti kita ketahui bersama bahwa persistensi laba merupakan laba yang mempunyai kemampuan sebagai indikator laba pada periode mendatang (future earnings) yang dihasilkan oleh perusahaan secara berulangulang (repetitive) dalam jangka panjang (sustainable) Sunarto, (2008). Laba yang dapat diprediksi tersebut haruslah di dukung oleh ketersediaan informasi, dan hal tersebut dapat diperoleh pada perusahaan-perusahaan yang besar, dibandingkan dengan perusahaan yang kecil. Informasi yang tersedia sepanjang tahun pada perusahaan besar memungkinkan pelaku pasar untuk menginterpretasikan informasi yang terdapat pada laporan keuangan dengan lebih sempurna, sehingga dapat memprediksi laba dengan lebih akurat.

Berdasarkan penjelasan tersebut dapat di simpulkan :

Ha3 - Ukuran Perusahaan (size) berpengaruh signifikan terhadap Persistensi Laba.

\section{Hubungan Arus Kas Operasi dengan Persistensi Laba dengan moderasi Audit Committee}

Arus kas dari kegiatan operasi (cash flow from operations atau CFO) merupakan indikator yang menentukan apakah kegiatan operasional perusahaan dapat menghasilkan arus kas yang cukup untuk melunasi pinjaman jangka pendek, memelihara kemampuan operasional perusahaan, dan membiayai pengeluaranpengeluaran untuk kegiatan operasional. Arus kas dari kegiatan operasi berisi penerimaan dan pengeluran kas yang diperoleh dan digunakan untuk kegiatan operasional perusahaan.

Manipulasi aktivitas riil merupakan manipulasi yang dilakukan oleh manajemen melalui aktivitas perusahaan sehari-hari selama periode akuntansi berjalan. Oleh karena itu, manipulasi ini dapat dilakukan kapan saja sepanjang periode akuntansi berjalan. Hal waktu (timing) inilah yang menjadi bagian penting perusahaan dalam hal ini manajer memiliki insentif melakukan manipulasi aktivitas riil. Teknik yang dapat dilakukan dalam manipulasi aktivitas riil antara lain manajemen penjualan, overproduction, dan pengurangan biaya diskresi (Roychowdhury, 2003).

Audit Committee merupakan seperangkat peraturan yang menetapkan hubungan antara pemegang saham, pengurus, pihak kreditur, karyawan serta pemegang kepentingan internal dan eksternal lainnya sehubungan dengan hakhak dan kewajiban mereka atau sistem yang mengarahkan dan mengendalikan perusahaan. Di dalam penulisan kali ini, penulis hanya memproksikan corporate governance dengan komisaris independen, kepemilikan manajerial, kepemilikan institusional dan kualitas audit. Dengan diterapkan nya Good Corporate Governance, diharapkan perusahaan tersebut dapat mengurangi atau menghindari aktivitas manipulasi aktivitas riil. Berdasarkan penjelasan tersebut dapat di simpulkan :

Ha4 - Audit Committee sebagai variabel moderating memiliki pengaruh signifikan dalam hubungannya antara Arus Kas Operasi dengan Persistensi Laba.

\section{Hubungan Tingkat Hutang dengan Persistensi} Laba dengan moderasi Audit Committee.

Menurut Beneish dan Press (dalam Herawaty dan Baridwan, 2007) Percepatan jatuh tempo, peningkatan tingkat bunga, dan negosiasi ulang masa hutang merupakan akibat yang dapat terjadi apabila perusahaan melanggar kontrak hutang. Hutang dapat meningkatkan manajemen 
laba saat perusahaan ingin mengurangi kemungkinan pelanggaran perjanjian hutang dan meningkatkan posisi tawar perusahaan selama negosiasi hutang (Klein, 2002 dan Othman dan Zhegal, 2006). Perusahaan akan berusaha menghindari default dengan membuat kebijaksanaan yang dapat meningkatkan pendapatan maupun laba, dengan demikian akan memberikan posisi bargaining yang relatif lebih baik dalam negosiasi atau penjadwalan utang-utang perusahaan (Jiambalvo, 1996 dalam Widyaningdyah, 2001:93). Perusahaan yang memiliki financial leverage tinggi akibat besarnya hutang dibandingkan aktiva yang dimiliki perusahaan, diduga melakukan manajemen laba karena perusahaan terancam default, yaitu tidak dapat memenuhi kewajiban membayar hutang pada waktunya (Shanti dan Yudhanti, 2007). Leverage yang tinggi juga akan meningkatkan perilaku oportunis manajemen seperti melakukan manajemen laba untuk mempertahankan kinerjanya di mata pemegang saham dan publik dan hal ini merupakan akibat dari kurangnya pengawasan. Konflik kepentingan antara prinsipal dan agen sering ditimbulkan akibat adanya hubungan antara keduanya hal tersebut terjadi biasanya disebabkan oleh munculnya biaya keagenan yang timbul karena agen tidak memenuhi keinginan prinsipal.

Audit Committee yang handal merupakan salah satu cara yang dapat dilakukan untuk menghindarikonflik tersebut. Konsep mekanisme good corporate governance dapat dilakukan demi meningkatnya kinerja perusahaan melalui supervisi atau monitoring kinerja manajemen dan menjamin akuntabilitas manajemen terhadap stakeholder dengan mendasarkan pada kerangka peraturan (Nasution dan Setiawan, 2007). Sejalan dengan itu, maka struktur dari Corporate Governance menjelaskan distribusi hak-hak dan tanggung jawab dari masing-masing pihak yang terlibat dalam sebuah bisnis, yaitu antara lain Dewan Komisaris dan Direksi, Manajer, Pemegang saham, serta pihak-pihak lain yang terkait sebagai stakeholders, Sedangkan menurut
Forum for Corporate Governance in Indonesia (FCGI, 2001) mendefinisikan corporate governance sebagai suatu perangkat peraturan yang menetapkan hubungan antara pemegang saham, pengurus, pihak kreditur, pemerintah, karyawan serta pemegang kepentingan internal dan eksternal lainnya sehubungan dengan hakhak dan kewajiban mereka.

Kepemilikan manajerial dapat ditingkatkan untuk mengurangi konflik keagenan. Kepemilikan manajemen terhadap saham perusahaan dipandang dapat menyelaraskan potensi perbedaan kepentingan antara pemegang saham luar dengan manajemen (Jensen dan Meckling, 1976). Kepemilikan manajerial yang tinggi akan membuat pemilik saham institusional akan mempunyai sedikit kesempatan kontrol pada perusahaan. Penelitian oleh Midiastuty dan Machfoedz (2003) menemukan bahwa adanya kepemilikan institusional yang tinggi membatasi manajer untuk melakukan pengelolaan laba (earnings management). Hasil penelitian Jiambalvo et al (dalam Herawati, 2008) menghasilkan nilai absolut diskresioner yang memiliki hubungan negatif dengan kepemilikan institusional. Dewan komisaris independen mempunyai tugas yaitu mensupervisi dan memberi nasehat kepada dewan direksi, dan memastikan bahwa perusahaan telah melaksanakan tanggung jawab kepada para stakeholder. Penelitian terdahulu yang mendukung, antara lain Jao dan Pagalung (2011) menyatakan bahwa perusahaan yang memiliki komposisi anggota dewan komisaris yang berasal dari luar perusahaan atau outside direktur dapat mempengaruhi tindakan manajemen laba. Dewan komisaris independen sangat berperan penting dalam mengawasi kinerja manajemen. Berdasarkan penjelasan tersebut dapat di simpulkan :

$\begin{aligned} \text { Ha5 - } & \text { Audit Committee sebagai variabel } \\ & \text { moderating memiliki pengaruh } \\ & \text { signifikan dalam hubungannya antara } \\ & \text { Tingkat Hutang dengan Persistensi } \\ & \text { Laba. }\end{aligned}$




\section{Hubungan Ukuran Perusahaan dengan Persistensi Laba dengan moderasi Audit Committee}

Perusahaan besar memiliki tingkat pengembalian (return) dan informasi yang lebih besar. Oleh sebab itu, investor lebih percaya kepada perusahaan besar dibandingkan perusahaan kecil dengan harapan memperoleh keuntungan (return) yang besar pula. Semakin tinggi kepercayaan investor, maka semakin tinggi pula persistensi labanya. Dengan demikian dapat dikatakan bahwa ukuran perusahaan berpengaruh positif terhadap persistensi laba. Dengan moderasi Good Coprporate Governance di dalam perusahaan tersebut, salah satunya komisaris independen, maka diharapkan manajemen laba dalam perusahaan tersebut dapat diminimalkan. Sesuai dengan pedoman good corporate governance guna menjaga independensi, pengambilan keputusan yang efektif, tepat, dan cepat. Adanya kepemilikan institusional dapat memantau secara profesional perkembangan investasi karena tingkat pengendalian terhadap manajemen sangat tinggi sehingga potensi kecurangan dapat ditekan.

Berdasarkan penjelasan tersebut dapat di simpulkan :

Ha6 - Audit Committee sebagai variabel moderating memiliki pengaruh signifikan dalam hubungannya antara
Ukuran Perusahaan dengan Persistensi Laba.

\section{Metode Penelitian}

Populasi dari penelitian ini adalah laporan keuangan perusahaan pertambangan yang terdaftar di Bursa Efek Indonesia, yang terdiri atas 25 perusahaan pertambangan periode 2012-2016. Alasan digunakan data perusahaan pertambangan mulai dari tahun 2012 adalah karena mulai periode tersebut terjadi fluktuasi yang sangat besar terhadap perusahaan pertambangan di Indonesia. Teknik pengambilan data pada penelitian ini menggunakan teknik purposive sampling, dimana sampling di dasarkan atas kriteria tertentu yang di tentukan oleh penulis.

Kriteria yang di gunakan untuk penentuan sampel dalam penelitian ini, antara lain :

1. Perusahaan pertambangan yang terdaftar di Bursa Efek Indnesia secara konsisten selama periode 2012-2016.

2. Perusahaan pertambangan yang terdaftar menerbitkan laporan keuangan yang berakhir 31 Desember 2012 - 31 Desember 2016.

3. Perusahaan pertambangan yang terdaftar tersebut secara berturut-turut tidak mengalami kerugian selama periode 20122016.

Tabel Definisi Operasional

\begin{tabular}{|c|c|c|c|}
\hline No & Variabel & Indikator Operasional & Sub Indikator \\
\hline \multirow[t]{2}{*}{1} & \multirow{2}{*}{$\begin{array}{l}\text { Arus Kas } \\
\text { Operasional } \\
\text { (X1) }\end{array}$} & \multirow{2}{*}{$\begin{array}{l}\text { Aliran kas operasi (PTCF) sebagai proksi } \\
\text { komponen laba permanen merupakan } \\
\text { aliran kas masuk dan kas keluar dari }\end{array}$} & Kas Operasi +pjk \\
\hline & & & Total Asset \\
\hline
\end{tabular}
aktivitas operasi sebelum pajak (pretax cash flow) yang dihitung sebagai total aliran kas operasi ditambah pajak penghasilan kemudian dibagi total aset (Fanani, Z . Fanani, Z. (2010) 2010). Semakin tinggi arus kas operasi suatu perusahaan maka laba perusahaan akan semakin persisten sebaliknya semakin rendah arus kas operasi perusahaan maka laba perusahaan semakin tidak persisten. Arus kas diukur dengan rumus. 
2 Ukuran

Perusahaan

(X2)

3

Leverage (X3)

4 Persistensi

Laba

$(\mathrm{Y})$
Romasari, 2013 Menyatakan bahwa ukuran perusahaan dapat menentukan baik, tidaknya kinerja perusahaan. Investor biasanya lebih memiliki kepercayaan pada perusahaan besar karena dianggap mampu untuk terus meningkatkan kinerja perusahaannya dengan berupaya meningkatkan kinerja perusahaannya dengan berupaya meningkatkan kualitas labanya. Pada saat pengumuman laba, informasi laba akan di respon positif oleh pasar. Dengan demikian semakin besar ukuran perusahaan akan membuat investor semakin merespon laba yang diumumkan.

Leverage merupakan rasio yang menghitung seberapa jauh dana yang disediakan oleh kreditur juga sebagai rasio yang membandingkan total hutang terhadap keseluruhan aktiva suatu perusahaan. Apabila investor melihat sebuah perusahaan dengan aset yang tinggi namun resiko leverage yang tinggi pula, maka akan berpengaruh pada keputusan investor untuk berinvestasi pada perusahaan tersebut.

Penman dan Zhang (2002), Persistensi Laba adalah revisi laba yang diharapkan dimasa mendatang (expected future earnings) yang diimplikasikan oleh inovasi laba tahun berjalan (current earnings) sehingga persistensi laba dilihat dari inovasi laba tahun berjalan yang dihubungkan dengan perubahan harga saham, semakin persisten laba maka semakin tinggi harapan peningkatan laba di masa datang.

\author{
Ukuran perusahaan $=\log$ \\ Penjualan
}

Romasari (2013) $\underline{\text { Total Hutang }}$

Total Ekuitas

Kashmir (2008)

$$
\text { Eit }=\beta 0+\beta 1 \text { Eit- } 1+\varepsilon \text { it }
$$

Teknik analisis data penelitian ini menggunakan analisis kualitatif, dengan menggunakan regresi linear berganda. Sebelum melakukan regresi di lakukan dulu uji statistik deskriptif dan uji asumsi klasik.

Uji Normalitas digunakan untuk menguji normal atau tidaknya pendistribusian data yang akan digunakan dalam penelitian. Dalam pengujian statistik akan lebih baik jika variabel terdistribusi normal. Jika variabel tidak terdistribusi normal maka hasil uji statistik akan tergradasi. Adapun Uji normalitas pada penelitian ini menggunakan uji statistik non parametrik Kolmogorov Smirnov (K-S).

Uji multikolonieritas bertujuan untuk menguji apakah Analisis regresi berganda ditemukan adanya korelasi antar variabel bebas (independen). Model regresi yang baik seharusnya tidak terjadi korelasi di antara variabel bebas. Jika variabel bebas saling berkolerasi, maka variabel-variabel ini tidak ortogonal. Variabel ortogonal adalah variabel bebas yang nilai korelasi antar sesama variabel bebas sama dengan nol. Untuk mendeteksi ada atau tidaknya multikolonieritas didalam model regresi tersebut adalah :

Nilai $\mathrm{R}^{2}$ yang dihasilkan suatu estimasi model regresi empiris sangat tinggi, tetapi secara individual variabel-variabel bebas banyak yang tidak signifikan mempengaruhi variabel 
terikat. Menganalisis matrik korelasi variabelvariabel bebas. Jika antar variabel bebas ada korelasi yang cukup tinggi (umumnya diatas 0.90), maka hal ini merupakan indikasi adanya multikolonieritas. Tidak adanya korelasi yang tinggi antar variabel bebas tidak berarti bebas dari kolonieritas. Multikolonieritas dapat disebabkan karena adanya efek kombinasi dua atau lebih variabel bebas. Multikolonieritas dapat juga dilihat dari nilai tolerance dan lawannya atau variance inflantion faktor (VIF). Kedua ukuran ini menunjukkan setiap variabel bebas manakah yang dijelaskan oleh variabel bebas lainnya. Dalam pengertian sederhana setiap variabel bebas menjadi variabel terikat dan diregresi terhadap variabel bebas lainnya. Nilai cutoff yang umum dipakai untuk menunjukkan adanya multikolonieritas adalah nilai tolerance $<0.10$ atau sama dengan nilai $\mathrm{VIF} \geq 10$.

Uji autokorerlasi adalah pengujian $\mathrm{Y}=\mathbf{a}+$ b1. X1 + b2. X2 + b3. X3 + b4. X1. Xm + b5. X2. Xm +b6. X3. Xm

Keterangan :

$\mathrm{Y}=$ Persistensi Laba

$\mathrm{X} 1=$ Arus Kas Operasi

$\mathrm{X} 2=$ Tingkat Utang

$\mathrm{X} 3=$ Ukuran Perusahaan

$\mathrm{Xm}=$ Audit Commitee

$\mathrm{a}=$ Konstanta

e $=$ Standar error

\section{Hasil dan Pembahasan}

Hasil penelitian dapat dilihat dalam tabel berikut :

Coefficients $^{\mathrm{a}}$

\begin{tabular}{|c|c|c|c|c|c|c|}
\hline \multicolumn{7}{|c|}{ Coefficients $^{a}$} \\
\hline \multirow{2}{*}{\multicolumn{2}{|c|}{ Model }} & \multicolumn{2}{|c|}{ Unstandardized Coefficients } & \multirow{2}{*}{$\begin{array}{c}\begin{array}{c}\text { Standardized } \\
\text { Coefficients }\end{array} \\
\text { Beta }\end{array}$} & \multirow[b]{2}{*}{$\mathrm{t}$} & \multirow[b]{2}{*}{ Sig. } \\
\hline & & $\mathrm{B}$ & Std. Error & & & \\
\hline \multirow{7}{*}{1} & (Constant) & ,965 & ,697 & & 1,384 &, 171 \\
\hline & $\mathrm{OCF}$ & ,323 & ,018 &, 881 & 17,959 &, 000 \\
\hline & Leverage & 1,774 & ,363 & ,383 & 4,893 &, 000 \\
\hline & SIZE &,- 026 & ,039 &,- 048 &,- 654 &, 515 \\
\hline & OCF_M & 4,859 & 4,518 & 1,395 & 1,076 & ,286 \\
\hline & LEV_M & $-5,525$ & 1,229 &,- 360 & $-4,496$ &, 000 \\
\hline & SIZE_M & ,083 &, 083 &, 071 & ,989 &, 326 \\
\hline
\end{tabular}

a. Dependent Variable: Persistensi

Sumber : data diolah dalam model regresi linier berganda terhadap korelasi antara kesalahan pengganggu pada periode $\mathrm{t}$ dengan kesalahan pengganggu pada periode t-1 (sebelumnya). Jika terjadi korelasi, maka dinamakan ada problem autokorelasi. Autokorelasi muncul karena observasi yang berurutan sepanjang waktu berkaitan satu sama lainnya. Masalah ini timbul karena residual (kesalahan pengganggu) tidak bebas dari satu observasi ke observasi lainnya. Hal ini sering ditemukan pada data runtu waktu (time series). Model regresi yang baik adalah regresi yang bebas dari autokorelasi. Untuk mendeteksi ada tidaknya autokorelasi ini dilakukan uji Durbin Watson. Uji Durbin Watson hanya digunakan untuk autokorelasi tingkat satu dan mensyaratkan adanya intercept dalam model regresi dan tidak ada variabel lagi diantara variabel independen.

Persamaan linear berganda dalam penelitian ini adalah sebagai berikut : 
Berdasarkan hasil uji hipotesis, dapat di simpulkan, hipotesis alternatif pertama (Ha1), menyatakan bahwa arus kas berpengaruh signifikan positif terhadap persistensi laba, berdasarkan hasil uji parameter statistik menunjukan bahwa t hitung sebesar 17,959> dari $\mathrm{t}$ tabel 2,73 pada tingkat signifikansi $5 \%$, artinya bahwa arus kas operasional berpengaruh signifikan positif terhadap persistensi laba. Kesimpulan nya : menerima Ha1 dan menolak H0. Hipotesis alternatif kedua (Ha2), menyatakan bahwa tingkat hutang berpengaruh signifikan positif terhadap persistensi laba, berdasarkan hasil uji parameter statistik menunjukan bahwa thitung sebesar 4,893 $>$ dari $\mathrm{t}$ tabel 2,73 pada tingkat signifikansi 5\%, artinya bahwa tingkat hutang berpengaruh signifikan positif terhadap persistensi laba. Kesimpulan nya : menerima Hal dan menolak H0. Hipotesis alternatif ketiga (Ha3), menyatakan bahwa ukuran perusahaan tidak berpengaruh terhadap persistensi laba, berdasarkan hasil uji parameter statistik menunjukan bahwa t hitung sebesar $-0,654<$ dari $t$ tabel 2,73 pada tingkat signifikansi $5 \%$, artinya bahwa tingkat hutang tidak berpengaruh terhadap persistensi laba. Kesimpulan nya: menolak Hal dan menerima H0. Hipotesis alternatif ke empat (Ha4), menyatakan bahwa arus kas operasional dengan moderasi audit commitee tidak berpengaruh terhadap persistensi laba, berdasarkan hasil uji parameter statistik menunjukan bahwa t hitung sebesar $1,076<$ dari $t$ tabel 2,73 pada tingkat signifikansi 5\%, artinya bahwa tingkat arus kas operasional dengan moderasi audit commisision tidak berpengaruh terhadap persistensi laba. Kesimpulan nya : menolak Ha1 dan menerima H0. Hipotesis alternatif ke lima (Ha5), menyatakan bahwa tingkat hutang dengan moderasi audit commisision tidak berpengaruh terhadap persistensi laba, berdasarkan hasil uji parameter statistik menunjukan bahwa t hitung sebesar $-4,496<$ dari $t$ tabel 2,73 pada tingkat signifikansi 5\%, artinya bahwa tingkat arus kas operasional dengan moderasi audit commisision tidak berpengaruh terhadap persistensi laba. Kesimpulan nya : menolak Ha1 dan menerima H0. Hipotesis alternatif ke enam (Ha6), menyatakan bahwa ukuran perusahaan dengan moderasi audit commisision tidak berpengaruh terhadap persistensi laba, berdasarkan hasil uji parameter statistik menunjukan bahwa t hitung sebesar $0,989<$ dari $\mathrm{t}$ tabel 2,73 pada tingkat signifikansi 5\%, artinya bahwa tingkat arus kas operasional dengan moderasi audit commisision tidak berpengaruh terhadap persistensi laba. Kesimpulan nya : menolak Ha1 dan menerima $\mathrm{H} 0$.

\section{Uji Koefisien Determinasi (R2)}

Model Summary

\begin{tabular}{llrrr}
\hline Model & $\mathrm{R}$ & $\begin{array}{c}\mathrm{R} \\
\text { Square }\end{array}$ & $\begin{array}{c}\text { Adjusted } \mathrm{R} \\
\text { Square }\end{array}$ & $\begin{array}{c}\text { Std. Error of the } \\
\text { Estimate }\end{array}$ \\
\hline 1 &, $913^{\mathrm{a}}$ &, 833 &, 821 & 1,04763 \\
\hline
\end{tabular}

a. Predictors: (Constant), OCF_M, LEV_M, SIZE_M, SIZE, Leverage

Sumber : data diolah

Berdasarkan hasil uji koefisien determinasi diatas, nilai Adjusted R Square sebesar 0,821 yang berarti persistensi laba yang dapat dijelaskan oleh variabel arus kas operasi, ukuran perusahaan, tingkat utang, X1.Xm, X2.Xm, X3.Xm sekitar $82,1 \%$. Sisanya sebesar 16,7 $\%$ dipengaruhi oleh variabel lain yang belum diteliti dalam penelitian ini.
Hasil pengujian hipotesis penelitian ini sebagai berikut:

\section{Hasil Uji Hipotesa Alternatif Pertama (Ha1) \\ Hipotesis alternatif pertama (Ha1) menyatakan bahwa arus kas operasional berpengaruh signifikan positif terhadap persistensi laba. Berdasarkan pemikiran secara logis menunjukkan bahwa perusahaan yang}


memiliki arus kas operasional yang tinggi menunjukkan tingkat likuiditas yang tinggi, tingkat likuiditas yang tinggi menunjukkan kemampuan perusahaan dalam memenuhi kewajiban jangka pendeknya yang jatuh tempo, sehingga besarnya kemampuan ini dapat menciptakan besarnya laba yang maksimal yang biasanya di proksikkan sebagai persistensi laba. Dengan demikian maka semakin tinggi arus kas operasional maka akan semakin tinggi pula pendapatan bersih yang mencerminkan persistensi laba.

Hal ini sesuai dengan penelitian yang dilakukan oleh Savitri (2014), bahwa informasi arus kas dapat memberikan gambaran mengenai hasil kinerja perusahaan yang sesungguhnya selama periode tertentu. Laba bersih kadangkadang tidak memberikan gambaran yang akurat mengenai hasil kinerja perusahaan sesungguhnya selama periode tertentu. Salah satu cerminan kinerja perusahaan adalah persistensi laba. Perusahaan dengan persistensi laba yang tinggi, laba bersih yang dihasilkan tidak menjamin bahwa perusahaan tersebut memiliki uang kas yang cukup untuk memenuhi kebutuhan kas jangka pendeknya. Qodriyah (2012), juga berpendapat bahwa laporan informasi arus kas operasi dapat dijadikan alat pengecekan atas informasi laba dan sebagai pengukur kinerja perusahaan. Kinerja perusahaan ini dapat dilihat dari persistensi laba perusahaan. Informasi arus kas bermanfaat dan memiliki pengaruh terhadap persistensi laba perusahaan karena laporan arus kas memberikan informasi apapun yang ingin diketahui mengenai kinerja perusahaan selama periode tertentu. Penelitian ini sesuai dengan teori kegunaan-keputusan (decisionusefulness theory) yang memiliki tujuan untuk memberikan informasi yang relevan dan tepat waktu agar berguna dalam pengambilan keputusan investasi, monitoring, penghargaan kinerja, dan pembuatan kontrak. Agar tujuan itu tercapai maka laba perusahaan harus persisten (Darraough, 1993). Hasil penelitian ini juga sejalan dengan penelitian yang dilakukan oleh Asma (2013), bahwa arus kas operasi berpengaruh positif terhadap persistensi laba. Nasir dan Ulfah (2008) dan Sloan (1996), juga menyatakan aliran kas operasi berpengaruh positif terhadap persistensi laba mengisyaratkan semakin tinggi aliran kas operasi suatu perusahaan maka akan meningkatkan persistensi laba perusahaan tersebut.

\section{Hasil Uji Hipotesa Alternatif kedua (Ha2)}

Hipotesis alternatifkedua (Ha2) menyatakan bahwa tingkat hutang berpengaruh signifikan positif terhadap persistensi laba. Berdasarkan pemikiran secara logis menunjukkan bahwa perusahaan yang memiliki tingkat hutang yang tinggi mempunyai arus kas yang tinggi pula, sehingga dapat melakukan kegiatan operasional yang dapat menciptakan besarnya laba yang maksimal yang biasanya di proksikkan sebagai persistensi laba. Dengan demikian maka semakin tinggi tingkat hutang semakin tinggi pula pendapatan bersih yang mencerminkan persistensi laba.

Penelitian ini sejalan dengan penelitian Fanani (2010) yang menyatakan bahwa tingkat hutang akan meningkatkan kinerja perusahaan, namun terdapat biaya bunga yang tinggi yang harus di bayar oleh perusahaan dalam jangka waktu tertentu. Scott (2003) menyatakan bahwa semakin tinggi tingkat utang perusahaan maka laba yang diperoleh perusahaan akan lebih banyak dialokasikan untuk kreditur daripada pemegang saham. Hasil penelitian Pagalung (2006) yang menguji tentang kualitas informasi laba dengan faktor penentu dan konsekuensinya menemukan bukti bahwa terdapat pengaruh yang positif antara tingkat hutang dengan persistensi laba, dan hasil penelitian serupa juga di dapat dari penelitian Junawatiningsih dan Harto (2014) yang berkesimpulan bahwa tingkat hutang berpengaruh positif terhadap persistensi laba. 


\section{Hasil Uji Hipotesa Alternatif ketiga (Ha3)}

Hipotesis alternatif ketiga (Ha3) menyatakan bahwa ukuran perusahaan berpengaruh signifikan negatif terhadap persistensi laba. Berdasarkan pemikiran secara logis menunjukkan bahwa perusahaan yang memiliki ukuran perusahaan yang tinggi mempunyai kemampuan dalam menghasilkan laba yang tinggi pula, sehingga dapat memiliki persistensi laba yang tinggi. Kenyataan yang ada menunjukkan bahwa ukuran perusahaan yang besar tidak menjamin laba yang besar. Dengan demikian hipotesa yang menyatakan bahwa semakin tinggi tingkat hutang semakin tinggi pula pendapatan bersih tidak selamanya benar, maka hipotesis ketiga ditolak. Selain itu dalam penelitian ini ukuran perusahaan dihitung berdasarkan logaritma dari total aset perusahaan sehingga naik atau turunnya aset dapat menyebabkan berubahnya nilai ukuran perusahaan. Romasari (2013), menyatakan bahwa investor menganggap perusahaan yang besar belum tentu memberikan keuntungan yang besar Efeknya, ukuran perusahaan tidak selalu dapat mencerminkan keadaan yang sebenarnya dari persistensi laba suatu perusahaan. Oleh karena itu, investor lebih memilih melihat kondisi pasar perusahaan secara umum daripada melihat total asetnya. Dengan begitu, laba yang dihasilkan cenderung kecil dan tidak persisten serta tidak mencerminkan kualitas laba yang sesungguhnya yang dihasilkan oleh perusahaan. Hal yang sama diungkapkan oleh Saputro (2011) menyatakan bahwa ukuran perusahaan tidak berpengaruh terhadap persistensi laba. Namun penelitian ini bertentangan dengan hasil penelitian yang di lakukan oleh Junawatiningsih dan Harto (2014) dan penelitian Dewi dan Putri (2015).

\section{Hasil Uji Hipotesa Alternatif keempat (Ha4)}

Hipotesis alternatif ketiga (Ha4) menyatakan bahwa audit committe sebagai variabel moderasi arus kas operasional tidak berpengaruh signifikan terhadap persistensi laba. Berdasarkan pemikiran secara logis menunjukkan bahwa komisi audit ternyata tidak bisa mempengaruhi arus kas operasional terhadap perisitensi laba. Hal ini berarti bahwa hipotesis keempat yang mengatakan bahwa audit committe memoderasi pengaruh positif arus kas operasi terhadap persistensi laba tidak terbukti.

\section{Hasil Uji Hipotesa Alternatif kelima (Ha5)}

Hipotesis alternatif ketiga (Ha5) menyatakan bahwa audit committe sebagai variabel moderasi tingkat hutang terhadap persistensi laba berpengaruh signifikan terhadap persistensi laba. Berdasarkan pemikiran secara logis menunjukkan bahwa audit committe yang baik dapat menjadi alat kontrol untuk memantau dan mendisiplinkan manajer agar lebih terfokus pada nilai perusahaan, dan audit committe memiliki kemampuan untuk mengendalikan pihak manajemen melalui proses pengawasan secara efektif sehingga hutang perusahaan benar-benar digunakan untuk operasional perusahaan guna meningkatkan laba perusahaan. Dengan kata lain peran audit committe dapat mengendalikan perilaku oportunistik manajemen dalam mengelola laba. Hasil penelitian ini sesuai dengan penelitian Guercio dan Hawkins (1999) dan Hartzell dan Starks (2003) dalam Cornett et al. (2006) menemukan adanya bukti yang menyatakan bahwa tindakan pengawasan yang dilakukan oleh sebuah perusahaan dan pihak investor institusional dapat membatasi perilaku manajer. Dengan demikian, tindakan pengawasan perusahaan yang dilakukan oleh pihak kepemilikan institusional dapat mendorong manajer untuk lebih memfokuskan perhatiannya terhadap kinerja perusahaan sehingga akan membatasi perilaku manajer di dalam manajemen laba. Cornertt et al. (2006) menyimpulkan bahwa tindakan pengawasan perusahaan oleh kepemilikan institusional dapat mendorong manajer untuk lebih memfokuskan perhatiannya terhadap kinerja perusahaan sehingga akan mengurangi perilaku opportunistik atau mementingkan diri sendiri. 


\section{Hasil Uji Hipotesa Alternatif keenam (Ha6)}

Hipotesis keenam (H6) yang diajukan dalam penelitian ini adalah audit committe memoderasi ukuran perusahaan tidak berpengaruh terhadap persistensi laba. Berdasarkan pemikiran secara logis menunjukkan bahwa audit committe tidak signifikan berpengaruh positif terhadap nilai perusahaan. Kurang memadainya pengalaman audit committe berefek pada kemampuan audit committe dalam mengendalikan manajemen tidak maksimal. Mengekspresikan pendapat dalam kelompok besar umumnya memakan waktu, sulit, dan mengakibatkan kurangnya kekompakan pada dewan direksi. yang baik dapat menjadi alat kontrol untuk memantau dan mendisiplinkan manajer agar lebih terfokus

Martani dan Persada (2009), menyatakan bahwa ukuran perusahaan dapat memberikan efek gangguan (noise) dimana perusahaan dapat melakukan tax planning dengan cara investasi aset yang akan memberikan manfaat pajak efektif sehingga efek dari audit committe menjadi agak bias. Oleh sebab itu, variabel audit committe tidak dapat memperkuat atau memperlemah hubungan antara variabel ukuran perusahaan dan persistensi laba.

\section{Kesimpulan, Keterbatasan dan Saran}

Berdasarkan hasil pengujian atas variabelvariabel tersebut, maka dapat disimpulkan bahwa arus kas operasional berpengaruh signifikan positif terhadap persistensi laba pada perusahaan pertambangan yang terdaftar di BEI pada periode 2012-2016, dan tingkat hutang berpengaruh signifikan positif terhadap persistensi laba pada perusahaan pertambangan yang terdaftar di BEI pada periode 2012-2016. Dan ukuran perusahaan berpengaruh negatif terhadap persistensi laba pada perusahaan pertambangan yang terdaftar di BEI pada periode 2012-2016, Audit committe memoderasi arus kas operasi tidak berpengaruh terhadap persistensi laba pada perusahaan pertambangan yang terdaftar di BEI pada periode 2012-2016, dan Audit committe memoderasi tingkat hutang berpengaruh terhadap persistensi laba pada perusahaan pertambangan yang terdaftar di BEI pada periode 2012-2016.

Audit committe memoderasi ukuran perusahaan tidak berpengaruh signifikan terhadap persistensi laba pada perusahaan pertambangan yang terdaftar di BEI pada periode 2012-2016.

Dalam penelitian ini terdapat beberapa keterbatasan, antara lain variabel yang digunakan dalam penelitian ini terbatas pada variabel arus kas operasi, tingkat hutang, ukuran perusahaan, dan Audit committe, masih banyak variabel lain yang masih bisa di jadikan bahan penelitian. Selain itu sampel yang digunakan dalam penelitian ini hanya terfokus pada perusahaan pertambangan yang terdaftar Bursa Efek Indonesia periode 2012-2016. Untuk itu penelitian selanjutnya disarankan memperbesar jumlah sampel serta memperpanjang periode penelitian.

Saran dari peneliti bagi calon investor hasil penelitian ini digunakan sebagai dasar pertimbangan dalam melalukan investasi di pasar modal, oleh karena itu para investor diharapkan di dalam pengambilan keputusan berdasarkan rasio keuangan, antara lain : arus kas operasional, tingkat hutang dan ukuran perusahaan. Bagi Emiten yang bertujuan meningkatkan laba perusahaan atau bertujuan ekspansi usaha dianjurkan mempertimbangkan rasio-rasio keuangan, antara lain : arus kas operasional, tingkat hutang dan ukuran perusahaan. Karena arus kas operasional diperoleh dari laba perusahaan yang dapat mencerminkan persistensi laba, yang menunjukkan tingkat likuiditas yang tinggi dalam memenuhi kewajiban jangka pendek perusahaan yang menunjukkan kemandirian perusahaan.

Penelitian selanjutnya diharapkan dapat mengamati data perusahaan lain dan periode penelitian yang lebih panjang, dan juga variabel 
penelitian lainnya yang dapat berhubungan dengan persistensi laba. Beberapa variabel tersebut adalah likuiditas, volatilitas penjualan, tata kelola perusahaan, kualitas akrual, dan lain sebagainya.

\section{Daftar Referensi}

Asma, T. N. (2013). Pengaruh aliran kas dan perbedaan antara laba akuntansi dengan laba fiskal terhadap persistensi laba. Jurnal Akuntansi, 1(1).

Baridwan, Z., \& Herawati, N. (2007). Manajemen Laba pada perusahaan yang Melanggar Perjanjian Utang.

Chandrarin, G. (2003). The Impact of Accounting Methods for Transaction Gains (Losses) on The Earning Response Coefficients: The Indonesian Case. The Indonesian Journal of Accounting Research, 6(3).

Cornett, M. M., Marcus, A. J., \& Tehranian, H. (2008). Corporate governance and pay-for-performance: The impact of earnings management. Journal of financial economics, 87(2), 357-373.

Darrough, M. N. (1993). Disclosure policy and competition: Cournot vs. Bertrand. Accounting review, 534-561.

Del Guercio, D., \& Hawkins, J. (1999). The motivation and impact of pension fund activism. Journal of financial economics, 52(3), 293-340.

Dewi, N. P. L., \& Putri, I. A. D. (2015). Pengaruh Book-Tax Difference, Arus Kas Operasi, Arus Kas Akrual, Dan Ukuran Perusahaan Pada Persistensi Laba. E-Jurnal Akuntansi, 244-260.

Dira, K. P., \& Astika, I. B. P. (2014). Pengaruh Struktur Modal, Likuiditas, Pertumbuhan Laba, dan Ukuran Perusahaan pada Kualitas Laba. E-Jurnal Akuntansi, 64-78.

Fanani, Z. (2010). Analisis faktor-faktor penentu persistensi laba. Jurnal Akuntansi dan Keuangan Indonesia, 7(1), 109-123.

Fanani, Z. (2010). Analisis faktor-faktor penentu persistensi laba. Jurnal Akuntansi dan Keuangan Indonesia, 7(1), 109-123.

Ghozali, I. (2006). Aplikasi analisis multivariate dengan program SPSS. Badan Penerbit Universitas Diponegoro.

Hartzell, J. C., \& Starks, L. T. (2003). Institutional investors and executive compensation. The journal of finance, 58(6), 2351-2374.

Jackson, M. (2009). Book-tax differences and earnings growth(Doctoral dissertation, University of Oregon).

Jao, R., \& Pagalung, G. (2011). Corporate governance, ukuran perusahaan, dan leverage terhadap manajemen laba perusahaan manufaktur Indonesia. Jurnal akuntansi dan auditing, 8(1), 43-54.

Jensen, M. C., \& Meckling, W. H. (1976). Theory of the firm: Managerial behavior, agency costs and ownership structure. Journal of financial economics, 3(4), 305-360.

Jiambalvo, J. (1996). Discussion of "Causes and consequences of earnings manipulation: An analysis of firms subject to enforcement actions by the SEC". Contemporary Accounting Research, 13(1), 37-47.

Jumingan, D. SE. MMM Si.(2006). Analisis Laporan Keuangan.

Junawatiningsih, T., \& Harto, P. (2014). Analisis Pengaruh Mekanisme Internal dan Eksternal Corporate Governance terhadap Persistensi Laba. Diponegoro Journal of Accounting, 338-348.

Klein, A. (2002). Audit committee, board of director characteristics, and earnings management. Journal of accounting and economics, 33(3), 375-400.

Kusuma, B., \& Sadjiarto, R. A. (2014). Analisa pengaruh volatilitas arus kas, volatilitas penjualan, tingkat hutang, book tax gap, dan tata kelola perusahaan terhadap persistensi laba. Tax \& Accounting Review, 4(1), 53.

Martani, D., \& Persada, A. E. (2009). Pengaruh book tax gap terhadap persistensi laba. Jurnal Akuntansi Universitas Indonesia. 
Midiastuty, P. P., \& Machfoedz, M. U. (2003). Analisis hubungan mekanisme corporate governance dan indikasi manajemen laba. Simposium Nasional Akuntansi VI, 176-199.

Naimah, Z., \& Utama, S. (2006). Pengaruh ukuran perusahaan, pertumbuhan, dan profitabilitas perusahaan terhadap koefisien respon laba dan koefisien respon nilai buku ekuitas: Studi pada perusahaan manufaktur di Bursa Efek Jakarta. Simposium Nasional Akuntansi IX, 1, 26.

Nasir, M., \& Ulfah, M. (2008). Analisis Pengaruh Arus Kas Operasi Terhadap Harga Saham dengan Persistensi Laba sebagai Variabel Intervening. Jurnal Maksi, 8(1), 74-85.

Nasution, M., \& Setiawan, D. (2007). Pengaruh corporate governance terhadap manajemen laba di industri perbankan Indonesia. Simposium Nasional Akuntansi $X, 1(1), 1-26$.

Oktavianti, S. (2015). Pengaruh Ukuran Perusahaan, Modal Kerja, Arus Kas Terhadap Likuiditas (Studi Pada Perusahaan Manufaktur Sektor Industri Barang Konsumsi Yang Terdaftar Di Bursa Efek Indonesia Periode 20092013) (Doctoral dissertation, Universitas Widyatama).

Othman, H. B., \& Zeghal, D. (2006). A study of earnings-management motives in the Anglo-American and Euro-Continental accounting models: The Canadian and French cases. The International Journal of Accounting, 41(4), 406-435.

Pagalung, G. (2006). Kualitas informasi laba:: Faktor-faktor penentu dan konsekuensi ekonominya (Doctoral dissertation, Universitas Gadjah Mada).

Penman, S. H., \& Zhang, X. J. (2002). Accounting conservatism, the quality of earnings, and stock returns. The accounting review, 77(2), 237-264.

Qodriyah, R. D. L. (2012). Laba Atau Arus Kas Sebagai Parametek Kinerja
Perusahaan. Jurnal Akuntansi Dan Ekonomi Bisnis, 1(1).

Richardson, S., Tuna, I., \& Wu, M. (2003). Capital market pressures and earnings management: The case of earnings restatements. University of Pennsylvania, unpublished.

Romasari, S. (2013). Pengaruh Persistensi Laba, Struktur Modal, Ukuran Perusahaan dan Alokasi Pajak Antar Periode Terhadap Kualitas Laba (Studi Empiris pada Perusahaan Manufaktur yang Terdaftar di BEI). Jurnal Akuntansi, 1(2).

Roychowdhury, S. (2006). Earnings management through real activities manipulation. Journal of accounting and economics, 42(3), 335-370.

Savitri, E. (2014). Analisis Pengaruh Leverage Dan Siklus Hidup Terhadap Manajemen Laba Pada Perusahaan Real Estate Dan Property Yang Terdaftar Di Bursa Efek Indonesia. Jurnal Akuntansi, 3(1), 72-89.

Shanti, J. C., \& Yudhanti, C. B. H. (2007). Pengaruh Set Kesempatan Investasi dan Leverage Finansial terhadap Manajemen Laba. Jurnal Ekonomi Bisnis dan Akuntansi, 10(3), 49-70.

Sloan, R. G. (1996). Do stock prices fully reflect information in accruals and cash flows about future earnings?. Accounting review, 289-315.

Sunarto, S. Peran Persistensi Laba terhadap Hubungan antara Keagresifan Laba dan Biaya Ekuitas. Kajian Akuntansi, 2(1).

Suwito, E., \& Herawaty, A. (2005). Reaktualisasi Pendidikan dan Penelitian Akuntansi Dalam Meningkatkan Peran Profesi Akuntansi Di Era Global. Simposium Nasional Akuntansi, 8, 136-148.

Widyaningdyah, A. U. (2004). Analisis faktorfaktor yang berpengaruh terhadap earnings management pada perusahaan go public di Indonesia. Jurnal Akuntansi dan Keuangan, 3(2), 89-101. 